\title{
Spray-dried egg in the diet of dogs: implications for recovery nutritional, palatability and haematology
}

\section{Ovo spray-dried na dieta de cães: implicações no aproveitamento nutricional, palatabilidade e hematologia}

\author{
Talita Andrade ${ }^{1}$; Daniele Cristina de Lima²; Alina Stadnik Komarcheuski²; \\ Ananda Portella Félix ${ }^{3}$; Simone Gisele de Oliveira ${ }^{3 *}$; Alex Maiorka ${ }^{3}$
}

\begin{abstract}
There is a growing demand for alternative protein sources in dog nutrition due to the high cost of the ingredient. Spray-dried egg (SDE) is a potential protein source in this context. The objective of this study was to evaluate the digestibility, palatability, and blood profile of diets containing different amounts of spray-dried egg (SDE) and the blood parameters of dogs fed these diets. For the study of digestibility and faecal quality (Experiment 1), eight Beagles were distributed in a double Latin square design (4X4), with four treatments $(0,4,8$, and $12 \% \mathrm{SDE})$ and four periods, totalling eight repetitions per treatment. In experiment 2 , to evaluate palatability, 20 dogs were presented with two diets: $0 \%$ SDE $v s 4 \%$ SDE. To evaluate the haematological factors (Experiment 3), eight dogs were maintained in a single group and were initially fed a control diet $(0 \% \mathrm{SDE})$ for 10 days, followed by a diet containing $12 \%$ SDE for 10 days. In Experiment 1, a linear increase was found in the coefficients of total tract apparent digestibility (CTTAD) of dry matter (DM) and crude protein (CP) and in the metabolisable energy (ME) as the level of SDE was increased in the diet. The CTTAD of DM and CP in SDE and the ME obtained by regression analysis were $93.6 \%, 91.3 \%$, and $5738.9 \mathrm{kcal} \mathrm{kg}^{-1}$, respectively, demonstrating that SDE is a highly digestible protein source for dogs. There were no changes in the stool characteristics of dogs fed SDE. The results of Experiment 2 indicate that the dogs preferred the diet that included 4\% SDE. In the haematological study (Experiment 3), increases in albumin, red blood cells, haemoglobin, and total circulating protein were observed, with no change in the other histological variables. The inclusion of SDE improved the digestibility and palatability of the diet and increased the albumin content, red blood cell count, haemoglobin level, and total protein level without changing the faecal characteristics.
\end{abstract}

Key words: Blood parameters. Digestibility. Dogs. Leukocytes. Protein sources.

\section{Resumo}

Há uma demanda crescente de fontes proteicas alternativas na nutrição de cães devido ao alto custo deste ingrediente. O ovo seco por pulverização (SDE) é uma fonte potencial de proteína neste contexto. O objetivo deste estudo foi avaliar a digestibilidade, palatabilidade e perfil sanguíneo de dietas contendo diferentes níveis de ovo spray-dried (OSD) e os parâmetros sanguíneos de cães alimentados com esta dieta. Para o estudo de digestibilidade e características fecais (Experimento 1), oito cães foram

\footnotetext{
${ }^{1}$ Discente, Programa de Pós-Graduação em Ciências Veterinárias, Universidade Federal do Paraná, UFPR, Curitiba, PR, Brasil. E-mail: talidrade@yahoo.com.br

2 Discentes, Programa de Pós-Graduação em Zootecnia, UFPR, Curitiba, PR, Brasil. E-mail: daniele.escrobot@gmail.com; alina. stadnik@yahoo.com.br

3 Profs., Departamento de Zootecnia, UFPR, Curitiba, PR, Brasil. E-mail: apfelix@ufpr.br; sgoliveira@ufpr.br; amaiorka@ufpr.br

* Author for correspondence
} 
distribuídos em delineamento quadrado latino duplo $(4 x 4)$, com quatro tratamentos $(0,4,8$ e $12 \%$ OSD) e quatro períodos, totalizando oito repetições por tratamento. No experimento 2, para avaliar a palatabilidade, 20 animais foram apresentados a duas dietas: $0 \%$ OSD vs 4\% OSD. Para avaliar os fatores hematológicos (Experimento 3), oito cães foram mantidos em um único grupo e foram inicialmente alimentados com a dieta controle ( $0 \%$ OSD) por 10 dias, seguido pela dieta contendo $12 \%$ OSD por 10 dias. No experimento 1, foi observado aumento linear para os coeficientes de digestibilidade aparente total (CDAT), da matéria seca (MS), e da proteína bruta (PB) e a energia metabolizável (EM) com o aumento de OSD da dieta. Os CDA da MS e PB em OSD e a EM obtidas pela análise da regressão foram de $93.6 \%, 91.3 \%$ e $5738.9 \mathrm{kcal} \mathrm{kg}^{-1}$, respectivamente, demonstrando que o OSD é uma fonte proteica de alta digestibilidade para cães. Não houve mudanças nas características fecais de cães alimentados com OSD. Os resultados do experimento 2 indicam que os cães preferiram a dieta com inclusão de 4\% de OSD. No estudo hematológico (Experimento 3), aumento de albumina, células vermelhas do sangue, hemoglobina e proteína total circulante foram observados, não houve mudança em outras variáveis histológicas. A inclusão de OSD melhorou a digestibilidade e palatabilidade da dieta e aumentou o teor de albumina, a contagem de células vermelhas, o nível de hemoglobina e o nível de proteína total sem alterar as características fecais.

Palavras-chave: Parâmetros sanguíneos. Digestibilidade. Cães. Leucócitos. Fontes proteicas.

\section{Introduction}

Considered a food industry by-product, spraydried egg (SDE) is obtained by spray drying eggs that are cracked, broken, or, for any reasons, not destined for human intake ratio (AAFCO, 2008).

The growth of the pet industry has led to the search for alternative protein sources with high digestibility and acceptability by animals, given the high cost of protein sources in diet formulations. In this context the inclusion of SDE in dog food may be interesting because, this ingredient is an excellent source of protein, there is good balance of amino acids, high digestibility and metabolizable energy (NORBERG et al., 2004).

The SDE may be a good source of methionine and can replace synthetic methionine (BURLEY et al., 2017). In addition to methionine, it also shows good levels of tryptophan and valine (SONG et al., 2015). SDE is a highly nutritious protein source, consisting $51.54 \%$ protein.

Furthermore, it is considered an excellent source of immunoglobulins, containing $150 \mathrm{mg}$ of gamma globulin per unit (TEIXEIRA et al., 2008), which remains mostly intact and active when subjected to drying in a spray dryer. Thus, SDE may have a contribution that is beyond the supply of nutrients (SONG et al., 2015).
However, the scarcity of studies of SDE limits the use of this protein source of nutrition for dogs. Taking into consideration the importance of protein sources in dog nutrition, this study aimed to evaluate the possible changes in digestibility, faecal characteristics, palatability, and haematological parameters introduced by the use of SDE in dog diets.

\section{Materials and Methods}

The nutritional study of SDE involved three experiments designed to evaluate the digestibility, palatability, and haematological parameters of dogs. The experiments were approved by the Ethics Committee on the use of Animals of the Agricultural Sciences Sector, Federal University of Paraná, Curitiba, PR, Brazil, (046/2011).

\section{Experiment 1: digestibilityandfaecal characteristics}

Diets

Four diets were formulated to evaluate four inclusion levels of SDE: $0,4,8$, and $12 \%$. The ingredients were milled in a hammer mill equipped with a $0.8 \mathrm{~mm}$ screen, mixed, and extruded in a single screw extruder (Ferraz, Ribeirão Preto, Brazil). The density of the extrudates produced 
by the extruder was considered adequate when the values were between 428 and $462 \mathrm{~g} \mathrm{l}^{-1}$. After extrusion, the diets were dried in a drier with three conveyors $\left(100-110^{\circ} \mathrm{C}\right)$ and sprayed with chicken oil. The SDE was added as a top dressing after the addition of liquid and powdered flavouring. The diets were stored for 15 days in closed bags and protected under pallets from direct sunlight. The ingredients and the analysed chemical composition of the diets are presented in Table 1.

Table 1. Ingredients and the analysed chemical composition of spray-dried egg (SDE) and experimental diets.

\begin{tabular}{|c|c|c|c|c|c|}
\hline & & \multicolumn{4}{|c|}{ SDE $(\%)$} \\
\hline & & 0 & 4 & 8 & 12 \\
\hline \multicolumn{6}{|l|}{ Ingredients ( $\%$, as fed) } \\
\hline Corn & & 47.21 & 45.32 & 43.43 & 41.55 \\
\hline Poultry offal meal & & 37.50 & 36.00 & 34.5 & 33.00 \\
\hline SDE & & - & 4.00 & 8.00 & 12.00 \\
\hline Poultry fat & & 10.00 & 9.60 & 9.20 & 8.80 \\
\hline Liquid poultry liver hydrolysate & & 3.00 & 2.88 & 2.76 & 2.64 \\
\hline Powdered poultry liver hydrolysate & & 1.00 & 0.96 & 0.92 & 0.88 \\
\hline Mineral and vitamin supplement ${ }^{1}$ & & 0.50 & 0.48 & 0.46 & 0.44 \\
\hline Sodium chloride & & 0.50 & 0.48 & 0.46 & 0.44 \\
\hline Butyl-hydroxy-toluene & & 0.05 & 0.05 & 0.05 & 0.04 \\
\hline Ammonium propionate & & 0.24 & 0.23 & 0.22 & 0.21 \\
\hline \multicolumn{6}{|c|}{ Analysed chemical composition (\%, dry matter basis) } \\
\hline & SDE & & & & \\
\hline Dry matter & 97.00 & 93.00 & 92.80 & 93.30 & 93.30 \\
\hline Crude protein & 52.78 & 28.82 & 29.85 & 30.01 & 31.75 \\
\hline Ether extract after acid hydrolysis & 29.67 & 26.70 & 24.86 & 23.05 & 25.13 \\
\hline Ash & 3.92 & 8.06 & 7.65 & 7.72 & 7.72 \\
\hline Crude fibre & - & 1.90 & 1.78 & 1.82 & 1.60 \\
\hline Gross energy $\left(\mathrm{kcal} \mathrm{kg}^{-1}\right)$ & 6018 & 5050 & 5102 & 5125 & 5184 \\
\hline
\end{tabular}

${ }^{1}$ Enrichment per kg offood: Vitamin A - 16900 I U, Vitamin D3 - 2340 I U, Vitamin E - 104 ppm, Vitamin K - 1.3 ppm, Vitamin B1 - 3.9 ppm, Vitamin B2 - 6.5 ppm, pantothenicacid- 19.5 ppm, niacin- 32.5 ppm, choline- 1150.75 ppm, iron- 104 ppm, copper- 13 ppm, iodine- $2.6 \mathrm{ppm}$, manganese- $45.5 \mathrm{ppm}$, selenium- $0.26 \mathrm{ppm}$.

\section{Animals, facilities, and digestibility study}

Eight adult dogs $(3 \pm 0.2$ years old $)$ of the Beagle breed were used in this study: four males with an average weight of $12 \mathrm{~kg}( \pm 1.2 \mathrm{~kg})$ and four females with an average weight of $10 \mathrm{~kg}( \pm 1.1 \mathrm{~kg})$. The dogs were healthy, vaccinated, dewormed, housed individually in brick stalls with a rough concrete floor measuring $5 \times 2 \mathrm{~m}$, and provided with shelter and a solarium.

The study was conducted using the total faecal collection method according to the recommendations of the Association of American Feed Control (AAFCO, 2004). Each period consisted of five days of adaptation to the diets and facilities and five days of total faeces collection. The animals were fed twice a day (07:30 and 16:00) in sufficient quantities to meet their metabolizable energy requirements: $\left(\right.$ kcal d $\left.^{-1}\right)=130 \times$ Weight $^{0.75}$ according to the recommendations of the National Research Council (NRC) (2006). Water was supplied ad libitum.

The faeces samples were collected and weighed a minimum of two times per day, packaged in individual plastic containers, and stored in a freezer $\left(-14^{\circ} \mathrm{C}\right)$. During the faecal collection period, stool output, consistency, $\mathrm{pH}$ (331, Politeste Instrumentos de Teste LTDA, São Paulo, Brazi)), and faecal dry 
matter were evaluated. The stool consistency was evaluated using a score ranging from 1 to 5 ; a score of 1 indicated pasty and formless stools, and a score of 5 indicated well-formed, hard, and dry faeces (CARCIOFI et al., 2009).

At the end of the collection period, the collected faeces was thawed and dried in a convection oven at $55^{\circ} \mathrm{C}$. The faeces and diets were ground to $1 \mathrm{~mm}$, and the dry matter (DM), crude protein (CP, method 954.01), ash (method 942.05), and crude fibre (CF, method 962.10) content and ether extract in acid hydrolysis (EEAH, method 954.02) were analysed according to Association of the Official Analytical Chemists (AOAC, 1995). The gross energy (GE) was measured in a bomb calorimeter (Parr Instrument Co., Model 1261, Moline, IL, USA). The total tract apparent digestibility (CTTAD) and the metabolizable energy (ME) were estimated according to AAFCO standards (2004) using the equations:

CTTAD $=[(\mathrm{g}$ ingested nutrient $-\mathrm{g}$ excreted nutrient)/ $\mathrm{g}$ ingested nutrient]

$\operatorname{ME}(\mathrm{kj} / \mathrm{g})=\{\mathrm{kj} / \mathrm{g}$ GE intake $-\mathrm{kj} / \mathrm{g}$ faecal GE $[(\mathrm{g}$ CP intake $-\mathrm{g}$ faecal CP $) \times 5.23 \mathrm{kj} / \mathrm{g}]\} / \mathrm{g}$

\section{Statistical analysis}

The data were analysed according to double Latin square design (4X4), with four periods, four diets, and eight dogs, totalling eight replicates per treatment. The results were tested for normality (Shapiro-Wilk) and homogeneity of variance (Bartlett) and when this assumption was accepted, data were submitted to analysis of variance using the GLM procedures of SAS statistical package (version 8, SAS Institute Inc., Cary, NC, USA). Regression analysis at a $5 \%$ probability concentration using PROC REG was performed based on the percentage of SDE included and the CTTAD. The spray-dried egg levels were added in substitution of the same amount of the control diet $(\mathrm{Cd})$. The diets containing
SDE are referred as test diets (Td). The following equation was used to determine the individual digestibility of nutrients in: $\mathrm{CTTAD}_{\mathrm{Td}}=\mathrm{CTTAD}_{\mathrm{SDE}}$ $+\left(\mathrm{CTTAD}_{\mathrm{Cd}}-\mathrm{CTTAD}_{\mathrm{Td}}\right) \times \%$ contribution of the nutrient of the $\mathrm{Cd}$ in the $\mathrm{Td}$.

The faecal score was analysed using the KruskalWallis test at a probability of $5 \%$.

\section{Experiment 2: palatability}

\section{Animals and facilities}

Twenty adult dogs, 10 males and 10 females, were used and housed individually in concrete stalls with a solarium measuring $5 \mathrm{~m} \times 2 \mathrm{~m}$. The breeds, number, and weights of the dogs were as follows: Beagles (8; $12.1 \pm 1.3 \mathrm{~kg}$ ), Labradors (4; 28.2 $\pm 2.7 \mathrm{~kg}$ ), Basset Hounds $(4 ; 21.9 \pm 2.2 \mathrm{~kg})$, and Siberian Huskies $(4 ; 20.8 \pm 1.9 \mathrm{~kg})$. The dogs were previously examined, vaccinated, and dewormed (Drontal plus, Bayer, Belford Roxo, RJ, Brazil).

\section{Experimental protocol}

Palatability was measured using the method of food preference (GRIFFIN, 2003), which involved presenting the dogs with two diet options $(0 \% v s$ $4 \% \mathrm{SDE})$. The objective was to evaluate the effect of the SDE at the minimum inclusion level on the palatability and intake ratio of the diet.

The diets were formulated to contain $30 \%$ more than the maintenance energy requirement recommended by the NRC (2006) for dog maintenance: $\left(\mathrm{kcal} \mathrm{day}^{-1}\right)=130 \mathrm{x}$ body weight ${ }^{0.75}$ $+30 \%$, therefore, $\left(\mathrm{kcal}^{\mathrm{day}}{ }^{-1}\right)=169 \mathrm{x}$ body weight ${ }^{0.75}$ (FELIX et al., 2012). The dogs were subjected to a period of adaptation, where they were offered the two test diets in two different bowls. During the test phase, both diets were offered simultaneously in identical bowls once a day (17:00 hours), for a period of 30 minutes, for two consecutive days. The position of the bowls was changed daily so that the 
animals did not develop a habit of always eating in the same place. The intake ratio of each diet was calculated based on the total amount of feed offered subtracted from the amount of scraps in the bowl at the end of the 30 minutes period. To calculate the intake ratio of each feed, regular intake ratio of the diet was evaluated for two days. The first choice of the dogs was documented (first visit). Water was provided ad libitum.

Food preference was calculated based on the intake ratio of $\operatorname{diet} \mathrm{A}$ as:

Intake ratio $=[\mathrm{g}$ of diet $\mathrm{A}$ or $\mathrm{B}$ intake $/ \mathrm{g}$ of total food offered $(\mathrm{A}+\mathrm{B})] \mathrm{x} 100$.

\section{Statistical analysis}

The palatability data were analysed using 40 observations per test (20 dogs x two test days). The data obtained from the palatability study were first submitted to the Kruskal-Wallis test, which revealed no influence $(\mathrm{P}>0.05)$ of breed (Beagle, Labrador, Basset Hound, and Siberian Husky), sex (male and female), or days tested (day 1 and day 2) on the number of visits to the bowl with the control diet or in the intake ratio of the control diet. Thus, the intake ratio of the diets was analysed using a t-test processed by the SAS statistical analysis program (Version 8, SAS Institute Inc., Cary, NC, USA) to determine whether the ingestion differed from a 0.5 at a probability of $5 \%$. A greater than 0.5 ingestion of the diet, according to Student's t-test, indicates food preference for the control, while less than 0.5 ingestion of the diet indicates a preference for the test diet.

The number of first visits to the bowls containing the control diet and the 4\% SDE diet were analysed using the chi-square test at a probability of $5 \%$ (FELIX et al., 2012). The expected frequency was equal to 20 , as there were 40 observations of the first visit to the bowls.

\section{Experiment 3: haematological evaluation}

\section{Animals and facilities}

Eight adult Beagles were used (four males and four females) for the haematological evaluation. The animals were housed individually in brick stalls with concrete floors, measuring $5 \times 2 \mathrm{~m}$, and shelter and a solarium.

\section{Experimental protocol}

The haematological evaluation lasted 20 days and was performed over two periods. The first period, with a duration of 10 days, consisted of providing the control diet (without SDE) to all of the dogs; while the second period, also with a duration of 10 days, consisted of providing the same diet with the addition of $12 \%$ SDE to all dogs.

During the evaluations, the dogs were fed once per day in quantities sufficient to meet their energy needs according to the equation: $\left(\mathrm{kcal} \mathrm{day}^{-1}\right)=$ $130 \mathrm{x}$ weight $^{0.75}$ (NRC, 2006). At the end of each period, blood samples were collected stored in anticoagulant EDTA tubes from the animals via the jugular vein after fasting from food (23 hours) and water (12 hours). The samples were to analyse the complete blood count, $3 \mathrm{ml}$ of blood was collected in tubes with the anticoagulant EDTA. Another 3 $\mathrm{ml}$ of blood was collected without anticoagulant for serum analysis. The parameters evaluated included the number and concentration of red blood cells and haemoglobin, white blood cell count, and levels of albumin, globulin, plasma proteins, and total protein.

To measure the total protein and albumin levels, the commercial chemical kit Dialab ${ }^{\circledR}$ and a BS-200 (Mindray Chemistry Analyser ${ }^{\circledR}$ ) were used. The haematological analyses were performed using a BC 2800 (Mindray Auto-Haematologic Analyser ${ }^{\circledR}$ ). The blades for counting cells were stained by the rapid panotype method. 
The slides used for cell counts were stained using the rapid panoptic method. The amount of globulin was estimated mathematically by the differences obtained between the total proteins and albumin.

\section{Statistical analysis}

The data were evaluated according to a completely randomised design with eight repetitions using Student's t-test with a probability of $5 \%$ by the SAS statistical analysis program (Version 8, SAS Institute Inc., Cary, NC, USA).

\section{Results and Discussion}

\section{Experiment 1: digestibility and faecal characteristics}

The inclusion of SDE in the diets increased the CTTAD of DM and CP and the ME $(\mathrm{P}<0.05)$ but did not influence the values for the CTTAD of the other nutrients $(\mathrm{P}>0.05)$, as shown in Table 2 .

There were no differences in the production of faeces, stool consistency scores, $\mathrm{pH}$, and faecal dry matter for the dogs fed the diets containing increased levels of SDE ( $\mathrm{P}>0.05$, Table 2).

The results of coefficients of digestibility obtained by the inclusion of different levels of SDE in the diets are similar to those obtained by Figueiredo et al. (2003) who, when evaluating the inclusion of SDE in the diet of weaned piglets, observed digestibility values for DM, CP, GE, and $\mathrm{EE}$ of $80.8 \%, 82.0 \%, 87.1 \%$, and $70.5 \%$, respectively, in diets in which SDE replaced $30 \%$ of the reference diet.

Hannas et al. (2001) obtained lower values for the $\mathrm{CP}$ in $\mathrm{SDE}(48.62 \%)$, while an experiment conducted by Czarnecki-Mauldenand Rudnick (1990) in dogs reported that the CTTAD of DM in a diet containing $20 \%$ spray-dried egg was $84.9 \%$. This value is higher than that found in the present study, with a maximum inclusion of SDE of $12 \%$. These differences may be explained by the lack of standardisation in the processing of SDE and other raw materials.

It was not possible to estimate the CTTAD of EEAH and GE for the egg by regression analysis because the results were not significant for these variables. Overall, the literature is limited with respect to the evaluation of the CTTAD of isolated ingredients in dog diets (CARCIOFI, 2002), which suggests that more research should be conducted on this subject.

Table 2. Coefficients of total tract apparent digestibility (CTTAD) and metabolisable energy content (kcal $\mathrm{kg}$ ) of the diets containing spray dried egg (SDE), CTTAD of dry matter, crude protein of SDE, and faecal characteristics of eight dogs.

\begin{tabular}{|c|c|c|c|c|c|c|c|c|}
\hline \multirow{2}{*}{ Item } & \multirow{2}{*}{ SDE } & \multicolumn{4}{|c|}{ Level of SDE in the diet (\%) } & \multirow{2}{*}{ SEM } & \multicolumn{2}{|c|}{$\mathrm{P}$} \\
\hline & & 0 & 4 & 8 & 12 & & $\mathrm{~L}$ & $\mathrm{Q}$ \\
\hline CTTAD (\%) Dry matter & 93.6 & 82.5 & 82.8 & 83.1 & 83.8 & 0.46 & 0.023 & 0.599 \\
\hline Crude protein & 91.3 & 85.2 & 85.4 & 85.6 & 86.6 & 0.48 & 0.026 & 0.328 \\
\hline Ether extract & - & 95.6 & 95.6 & 95.4 & 95.8 & 0.23 & 0.524 & 0.197 \\
\hline Gross energy & - & 88.8 & 88.7 & 89.1 & 89.4 & 0.03 & 0.168 & 0.599 \\
\hline ME & - & 4036 & 4139 & 4196 & 4344 & 56.45 & 0.001 & 0.365 \\
\hline Faecal characteristics & & & & & & & & \\
\hline Dry matter(\%) & - & 35.8 & 35.81 & 35.35 & 35.66 & 2.34 & 0.315 & 0.05 \\
\hline Score $^{1}$ & - & 3.75 & 4.05 & 3.85 & 3.60 & 0.29 & - & - \\
\hline $\mathrm{pH}$ & - & 6.73 & 6.95 & 6.85 & 6.60 & 0.28 & 0.243 & 0.282 \\
\hline Faecal output ${ }^{2}$ & - & 0.10 & 0.13 & 0.13 & 0.12 & 0.02 & 0.248 & 0.060 \\
\hline
\end{tabular}

${ }^{1}$ Faecal score $(\mathrm{P}=0.7249$ by the Kruskal-Wallis test).

${ }^{2}$ Faecal production of fresh matter $[(\mathrm{g}) /$ dry matter intake $(\mathrm{g}) /$ day $]$.

SEM - standard error of the mean

P - Probability of linear (L) and quadratic (Q) effects. 
Regarding faecal characteristics, dogs fed SDE did not show alterations in the DM coefficient, $\mathrm{pH}$, and faecal volume. Similarly, Dust et al. (2005) found no significant difference in the faecal characteristics of dogs fed SDE. However, in the same study, the authors used a lower amount of SDE in the diet (3\%) and a different method, where the SDE was added to the diet along with the other ingredients before extrusion.

\section{Experiment 2: palatability}

In the diet palatability test, the first choice of the dogs was the test diet with $4 \% \operatorname{SDE}(\mathrm{P}<0.05$, Table $3)$. In the same manner, increased intake ratio was observed for the test diet compared to the control diet without the inclusion of $\operatorname{SDE}(\mathrm{P}<0.05$, Table 3$)$.

Table 3. Number of first visit to the pan with $\operatorname{diet} A(n)$ and intake ratio (I R + standard error) of dogs.

\begin{tabular}{llc}
\hline Diet A $v s \mathrm{~B}$ & $\mathrm{n}^{2}$ & $\mathrm{I}$ R of $\operatorname{diet} \mathrm{A}^{3}$ \\
\hline $0 \mathrm{SDE} v s 40 \mathrm{~g} \mathrm{~kg} \mathrm{SDE}^{1}$ & 23 & 0.52 \\
\hline
\end{tabular}

SDE - spray-dried egg.

${ }^{1}$ Value of $\mathrm{P}<0,05$ for number of visits to the diet A by chi-square test and I R by Student's $t$ test.

${ }^{2}$ Number of visits to food B is obtained by: 40 - n;

${ }^{3} \mathrm{IR}$ : [g of diet A or B intake/ $g$ of total food offered (A+B)] x 100. I R of diet B is calculated as 1 -IR of $\operatorname{diet} A$.

Various factors can influence the results of palatability, including the aroma and texture of the food and the shape and size of the extrudate (ARAUJO; MILGRAM, 2004). Even trained dogs can have preferences for a particular aroma, which can lead to greater intake ratio of that food.

According to Dust et al. (2005), SDE has high palatability and is also a good source of protein, which is consistent with the results obtained in this study, because dogs preferred and consumed the diet containing larger amounts of SDE. In studies involving pigs and poultry, a reduction of intake ratio was observed for diets containing SDE (FIGUEIREDO et al., 2003; TEIXEIRA et al., 2008). It is noteworthy that differences in the species studied can produce different results, as nutritional requirements vary between species, which will influence intake ratio.

\section{Experiment 3: Haematological evaluation}

The intake ratio of the diet containing 12\% SDE resulted in an increase, within normal ranges, of albumin, red blood cell, haemoglobin, and total protein levels $(\mathrm{P}<0.05)$.

The inclusion of SDE in the diet did not alter the other parameters $(\mathrm{P}>0.05)$, as shown in Table 4. The haematological responses generated by the administration of food, whether negative or positive, are extremely important for evaluating the quality and purpose of the food studied. The increases in serum levels of albumin, red blood cells, haemoglobin, and total protein may be due to the higher protein content provided to the dogs, as SDE is a highly nutritious product that provides $55.54 \%$ crude protein and $150 \mathrm{mg}$ of gamma globulin per unit, in addition to having a very balanced amino acid composition (TEIXEIRA et al., 2008). 
Table 4. Blood parameters of dogs first fed the control diet and then a diet containing 12\% spray-dried egg (SDE).

\begin{tabular}{lcccc}
\hline Parameters & $0 \%$ SDE & $12 \%$ SDE & SEM & P \\
\hline Erythrocytes $\left(\mathrm{mm}^{3}\right)$ & 3.36 & 3.64 & 0.04 & 0.001 \\
Haematocrit $(\%)$ & 2.67 & 2.77 & 0.09 & 0.373 \\
Haemoglobin $\left(\mathrm{g} \mathrm{dl}^{-1}\right)$ & 6.46 & 6.80 & 0.09 & 0.032 \\
Total leukocytes $\left(\mathrm{n} \mathrm{fl}^{-1}\right)$ & 45.07 & 46.00 & 0.75 & 0.448 \\
Blood proteins $\left(\mathrm{g} \mathrm{dl}^{-1}\right)$ & 15.61 & 16.84 & 0.28 & 0.016 \\
Total proteins $\left(\mathrm{g} \mathrm{dl}^{-1}\right)$ & 9414 & 9863 & 638 & 0.621 \\
Albumin $\left(\mathrm{g} \mathrm{dl}^{-1}\right)$ & 6.79 & 7.00 & 0.16 & 0.366 \\
Globulins $\left(\mathrm{g} \mathrm{dl}^{-1}\right)$ & 6.10 & 6.41 & 0.08 & 0.013 \\
\hline
\end{tabular}

SEM - standard error of the mean.

$\mathrm{P}$ - probability, considered significant when $\mathrm{P}<0.05$ using Student's t-test $(\mathrm{n}=8)$.

In studies conducted by Figueiredo et al. (2003) in newly weaned piglets, the substitution of blood plasma protein for SDE in different proportions did not change any haematological component evaluated in these animals. To date, no study has been found that performed this evaluation in dogs. Thus, further studies are needed to evaluate the influence of SDE on blood parameters in dogs.

\section{Conclusions}

The inclusion of up to $12 \%$ of SDE in dog foods increases the digestibility of some nutrients and the levels of some hematological parameters important for the health of these animals. This ingredient also provides greater diet acceptability with $4 \%$ inclusion. However, SDE decreases the fecal consistency of dogs.

\section{References}

ARAÚJO, J. A.; MILGRAM, N.W. A novel cognitive palatability assessment protocol for dogs. Journal Animal Science, Oxford, v. 82, n. 7, p. 2200-2208, 2004.

ASSOCIATION OF OFFICIAL ANALYTICAL CHEMISTS - AOAC. Official methods of analysis. $16^{\text {td }}$ ed. Arlington: AOAC International, 1995.

ASSOCIATION OF AMERICAN FEED CONTROL OFFICIALS - AAFCO. Dog and cat nutrient profiles. Oxford: AAFCO, 2004.
Editorial changes/Modifications to existing definistions in Ingredient definitions committee. Oxford: AAFCO, 2008.

BURLEY, H. K.; PATTERSON, P. H. Brazil nut meal and spray-dried egg pownders as alternative to synthetic methionine in organic laying hen diets. Poultry Science, Oxford, v. 96, n. 11, p. 3994-4005, 2017.

CARCIOFI, A. C. Proteína na alimentação de cães e gatos. In: SIMPÓSIO SOBRE NUTRIÇÃO DE ANIMAIS DE ESTIMAÇÃO, 2002. Campinas. Anais... Campinas: CBNA, 2002. p. 31-44.

CARCIOFI, A. C.; OLIVEIRA, L. D.; VALÉRIO, A. G.; BORGES, L. L.; CARVALHO, F. M.; BRUNETTO, M. A.; VASCONCELLOS, R. S. Comparison of micronized whole soybeans to common protein sources in dry dog and cat diets. Animal Feed Science and Technology, Oxford, v. 151, n. 3-4, p. 251-260, 2009.

CZARNECKI-MAULDEN, G. L.; RUDNICK, M. S. R. Development of a successful spray-dried egg whitebased experimental diet for dogs: Effect of heat treatment on diet utilization. Nutrition Research, Oxford, v. 10, n. 1, p. 109-115, 1990.

DUST, J. M.; GRIESHOP, C. M.; PARSONS, C. M.; KARR-LILIENTHAL， L. K.; SCHASTEEN, C. S.; QUIGLEY, J. D.; MERCHEN, N. R.; FAHEY JUNIOR, G. C. Chemical composition, protein quality, palatability, and digestibility of alternative protein sources for dogs. Journal Animal Science, Oxford, v. 83, n. 10, p. 24142422, 2005.

FELIX, A. P.; CARVALHO, M. P.; ALARÇA, L. G.; BRITO, C. B. M.; OLIVEIRA S. G.; MAIORKA, A. Effects of the inclusion of carbohydrases and different soybean meals in the diet on palatability, digestibility and faecal characteristics in dogs. Animal Feed Science and Technology, Oxford, v. 174, n. 3-4, p. 182-18, 2012. 
FIGUEIREDO, A. N.; MIYAHDA, V. S.; UTYIAMA, C. E.; LONGO F. A. O ovo em pó na alimentação de leitões recém-desmamados. Revista Brasileira de Zootecnia, Viçosa, v. 32, n. 6, p. 1901-1911, 2003.

GRIFFIN, R. Palatability testing methods: parameters and analyses that influence test conditions. In: MORRIS, I. L. Petfood technology. Watt Publishing Co., 2003. p. 187-193.

GRIFFIN, R. Palatability testing methods: parameters and analyses that influence test conditions. In: KVAMME, J. L.; PHILLIPS, T. D. (Ed.). Petfood technology. Watt Publishing, Mt. Morris, v. 1, 2003. p. 187-193.

HANNAS, M. I.; KRONKA, R. N.; THOMÁZ, M. C. Composição química, valores de energia e proteína digestíveis do plasma suíno e ovo desidratado por spray-dried para suínos. In: REUNIÃO ANUAL DA SOCIEDADE BRASILEIRA DE ZOOTECNIA, 38., 2001, Piracicaba. Anais... Piracicaba: Fundação de Estudos Agrários Luiz de Queiroz, 2001. p. 851-852.
NORBERG, S. E.; DILGER, R. N.; ADEOLA, O.; LATOUR, M. A. Utilization of energy and amino acids of spray-dried egg, plasma protein, and soybean meal by ducks. Poultry Science, Oxford, v. 83, n. 6, p. 934-945, 2004.

NATIONAL RESEARCH COUNCIL- NRC. Nutrient requirements of dogs and cats. 3rd rev. ed. Washington, DC: National Academic Press, 2006.

SONG, M.; KIM, S.; KIM, Y.; PARK, J.; KIM, Y. Value of spray-dried egg in pigs nursery diets. Journal of Agricultural Science, Toronto, v. 42, n. 3, p. 207-213, 2015.

TEIXEIRA, E. N. M.; SILVA, J. H. V.; RIBEIRO, M. L. G.; COSTA, F. G. P.; JORDÃO FILHO, J.; ARAÚJO, D. M. Inclusão de ovo desidratado em rações para frangos de corte nas fases pré-inicial e de crescimento. Revista Brasileira de Zootecnia, Viçosa, v. 37, n. 7, p. 12651270, 2008. 
